\title{
KOOPETYCJA MIĘDZYGMINNA W POLSKICH OBSZARACH METROPOLITALNYCH
}

Z a r y s t r e ś c i: W artykule podjęto problematykę relacji o charakterze koopetycyjnym (koopetycji) między gminami tworzącymi obszary metropolitalne w Polsce. Dokonano syntetycznej charakterystyki zakresów: podmiotowego (obszary metropolitalne) i przedmiotowego (koopetycja), w tym wskazano na miejsce i rolę obszarów metropolitalnych, ich problemy rozwojowe, pojęcie koopetycji oraz dylematy poznawcze z nią związane. Opracowanie stanowi przyczynek do dalszych badań nad koopetycją wewnątrz obszarów metropolitalnych.

S ło w a k 1 u c z o w e: kompetycja; konkurencja; kooperacja; obszary metropolitalne.

\section{WSTĘP}

Minęło już 25 lat od restytucji w Polsce jednostek samorządu terytorialnego na poziomie lokalnym - gmin [www.mac.gov.pl]. Polska gospodarka przeszła w tym czasie bardzo istotne zmiany systemowe, gospodarcze, społeczne, w tym również demograficzne. Najdynamiczniejsze etapy tychże przypadają na lata 90., którym bardzo często towarzyszyła głęboka restrukturyzacja. XXI w. również obfituje w liczne wyzwania, których kumulacji sprzyja coraz większa dynamika zmienności otoczenia, wzrost jego złożoności, a w konsekwencji narastająca niepewność [Jędralska,

* Adres do korespondencji: Maciej Koszel, Uniwersytet Ekonomiczny w Poznaniu, Wydział Zarządzania, Katedra Zarządzania Strategicznego, al. Niepodległości 10, 61-875 Poznań, e-mail: maciej.koszel@ue.poznan.pl 
Czech, 2011, s. 9]. Wyjątkowa rola w rozwoju społeczno-gospodarczym przypada obszarom metropolitalnym, które skupiają w sobie znaczny potencjał ludzki, organizacyjny, strukturalny, kapitałowy czy funkcjonalny. To w ich przypadku znacznie uwidaczniają się problemy rozwojowe. Obszary metropolitalne stanowią bowiem najbardziej złożone systemy funkcjonalne administracji terytorialnej. Ewenementem i swoistym paradoksem jest jednak brak oficjalnego wyodrębnienia w systemie administracyjno-terytorialnym oraz brak kompleksowych regulacji prawnych podstaw ich funkcjonowania. Przyczynia się to do nieefektywnego rozwoju obszarów metropolitalnych, narastania problemów rozwojowych i zwiększania się wewnętrznych dysproporcji [Izdebski, 2006; Grochowski, 2010; Mantey, 2013].

Jedną ze współczesnych koncepcji stymulowania rozwoju - w tym i rozwoju zrównoważonego - może być koopetycja, poprzez którą rozumie się wiązkę strumieni jednoczesnych relacji o charakterze konkurencji i kooperacji pomiędzy podmiotami zaangażowanymi [Cygler, 2007, s. 64] - w przypadku funkcjonowania obszarów metropolitalnych tożsamych z jednostkami samorządu terytorialnego - gminami, które tworzą obszar metropolitalny.

W artykule autor rozważa potencjalne możliwości zastosowania koopetycji w wymiarze funkcjonowania gmin tworzących obszary metropolitalne w Polsce. Wskazano na aspekty konkurencji i kooperacji międzygminnej (zakres koopetycji) oraz potencjalne korzyści wynikające z jej stosowania. Podjęto również wątek powiązania koopetycji ze zrównoważonym rozwojem. Główną oś rozważań w tym wymiarze stanowi wpływ koopetycji za zrównoważony rozwój obszarów metropolitalnych.

Opracowaniu artykułu służył przegląd i krytyczna analiza literatury polsko- i obcojęzycznej w zakresie koopetycji i funkcjonowania obszarów metropolitalnych.

\section{ROLA I MIEJSCE OBSZARÓW METROPOLITALNYCH W GOSPODARCE POLSKIEJ}

Obszary metropolitalne, w skład których wchodzi zazwyczaj ${ }^{1}$ miasto centralne (metropolia) oraz funkcjonalnie powiązane $\mathrm{z}$ nim, bezpo-

1 W Polsce większość obszarów metropolitalnych ma charakter monocentryczny - jedno miasto centralne i ośrodki satelickie. Wyjątek stanowi górnośląski obszar 
średnie otoczenie (gminy oraz miasta bezpośrednio z nim sąsiadujące), stanowią współcześnie najważniejsze ośrodki rozwoju krajowego systemu społeczno-gospodarczego [Markowski, Marszał, 2006, s. 15]. Często określane są mianem biegunów wzrostu gospodarczego. Świadczy o tym z jednej strony zakres funkcji, jakie realizują, a które określane są mianem metropolitalnych. Ich zasięg nie ogranicza się wyłącznie do skali regionalnej, ale w większości przypadków do krajowej i w miarę rozwoju wybranych obszarów metropolitalnych - międzynarodowej. $\mathrm{Z}$ drugiej strony obszary metropolitalne stanowią siedziby licznych organizacji (przedsiębiorstw, instytucji), które generują różnorakie produkty i usługi. Są wreszcie miejscem akumulacji różnego rodzaju zasobów: materialnych (aktywa, kapitał finansowy) i niematerialnych (zasoby ludzkie, kapitał intelektualny). Ich dynamiczny rozwój w ostatnim dwudziestoleciu wciąż napotyka jednak na liczne problemy - bariery, które dają swój silny wyraz właśnie w odniesieniu do funkcjonowania obszarów metropolitalnych. W tym właśnie kontekście wskazuje się na dysfunkcje metropolitalne. Problemy rozwojowe skupiają się wokół czterech głównych aspektów: ekonomicznego, społecznego, ekologicznego oraz przestrzennego [Parysek, Mierzejewska, 2009; Parysek, 2013]. Podstawową typologię można rozwijać oraz uszczegóławiać, jednak wskazane stanowią kanon, któremu poświęca się najwięcej publikacji naukowych.

Kwestia całkowitego rozwiązania problemów rozwojowych lub też ograniczenia ich negatywnego wpływu stanowi istotne wyzwanie, stojące przed władzami samorządowymi gmin tworzących obszary metropolitalne. Brak bowiem w warunkach polskich regulacji prawnych w zakresie funkcjonowania obszarów metropolitalnych, jako samodzielnych jednostek samorządu terytorialnego - wydzielonych administracyjnie i terytorialnie [Lackowska, 2009]. W związku z tym koordynacja i zarządzanie ich rozwojem leży w gestii pozasamorządowych organizacji i instytucji tworzonych w tym celu - zazwyczaj przyjmują one formę związków i stowarzyszeń lub porozumień gmin wchodzących w skład obszaru metropolitalnego. Zygmunt Niewiadomski [2008, s. 312-313] wskazuje, że zarządzanie obszarami wielkiego miasta wraz z jego bezpośrednim otoczeniem, czyli potencjalnymi obszarami metropolitalnymi, należy do zadań własnych jednostek samorządu terytorialnego na poziomie gminnym, które

metropolitalny oraz trójmiejski obszar metropolitalny, które mają charakter policentrycznych. 
realizują te zadania samodzielnie. W mniejszym stopniu odpowiedzialność zarządzania obszarami metropolitarnymi leży w gestii województw i powiatów. Kwestię tę podejmuje również Hubert Izdebski [2010, s. 64-65], który rozważa wprowadzenie jednostek samorządu terytorialnego szczebla NUTS 3 - wyłączenie obszarów metropolitalnych jako samodzielnych jednostek.

\section{WYZWANIA ROZWOJOWE OBSZARÓW METROPOLITALNYCH W POLSCE}

Funkcjonowanie terytorialnych systemów społecznych (miast, aglomeracji miejskich), w tym przede wszystkim obszarów metropolitalnych jako najbardziej złożonych funkcjonalnie i strukturalnie, obarczone jest licznymi problemami, które stanowią istotne wyzwania, a w wielu przypadkach znaczne bariery rozwojowe [Kowalewski, 2006]. Obszary metropolitalne, szczególnie zaś centralne miasto metropolitalne, jest miejscem kumulacji nie tylko specyficznych zasobów, miejscem realizacji funkcji o charakterze regionalnym, krajowym czy międzynarodowym, ale również miejscem występowania istotnych problemów rozwojowych o silnym natężeniu. Za J.J. Paryskiem [2013, s. 87] można wskazać na pięć głównych obszarów występowania tychże. Są to problemy związane z aspektem gospodarczym, społecznym (społeczno-kulturowym uwzględniającym kwestie instytucjonalne), przestrzennym (planowanie przestrzenne), środowiskowym (ekologicznym) oraz techniczno-technologicznym, który w głównej mierze odnosi się do spraw związanych z infrastrukturą. Lidia Mierzejewska [2010, s. 77] wskazuje zaś na cztery główne aspekty występowania wyzwań rozwojowych, które odzwierciedlają również autorski model zrównoważonego rozwoju miast uwzględniający cztery sfery - przyrodniczą, społeczną, gospodarczą i przestrzenną [Mierzejewska, 2010, s. 119]. Główne wyzwania rozwojowe miast i obszarów metropolitalnych przedstawiono w tabeli 1. 
Tabela 1. Główne wyzwania rozwojowe miast i obszarów metropolitalnych w Polsce

\begin{tabular}{|c|c|}
\hline Aspekt & Wyzwania \\
\hline Przyrodniczy & $\begin{array}{l}\text { - zapewnienie wysokich standardów jakości środowiska } \\
\text { naturalnego, } \\
\text { - racjonalna gospodarka wodna, } \\
\text { - racjonalna gospodarowanie odpadami, } \\
\text { - racjonalne zarządzanie energią i dostawami energii, } \\
\text { - zachowanie równowagi pomiędzy terenami zabudowanymi } \\
\text { a terenami zieleni, }\end{array}$ \\
\hline Społeczny & $\begin{array}{l}\text { - likwidacja dysproporcji w rozwoju i warunkach życia, } \\
\text { - przeciwdziałanie niekorzystnym trendom demograficznym, } \\
\text { - powstrzymanie pogłębiającego się rozwarstwienia społecz- } \\
\text { nego, } \\
\text { - zatrzymanie szerzenia się zjawisk patologicznych, a następ- } \\
\text { nie sanacja, } \\
\text { - przeciwdziałanie rozwojowi chorób cywilizacyjnych, } \\
\text { - zagwarantowanie bezpieczeństwa mieszkańcom, } \\
\text { - zapewnienie odpowiednich warunków mieszkańców i sani- } \\
\text { tarnych, } \\
\text { - współpraca różnych instytucji przy opracowywaniu strategii } \\
\text { rozwoju, }\end{array}$ \\
\hline Gospodarczy & $\begin{array}{l}\text { - sprostanie wzrastającej, międzynarodowej konkurencji, } \\
\text { - rozwój nowych dziedzin życia społecznego i gospodarczego, } \\
\text { - organizacja wydajnego i efektywnego ekonomicznie systemu } \\
\text { transportu publicznego, } \\
\text { - rozwiązywanie problemów finansowych powstałych w wyni- } \\
\text { ku coraz wyższych kosztów utrzymania, }\end{array}$ \\
\hline Przestrzenny & $\begin{array}{l}\text { - dbanie o ład przestrzenny - dążenie do stanu ładu rzeczywi- } \\
\text { stego, } \\
\text { - racjonalna gospodarka terenem, } \\
\text { - powstrzymanie rozlewania się miasta, } \\
\text { - jednorodność stylu architektonicznego, } \\
\text { - wzrost funkcjonalności terenu, } \\
\text { - wzrost poziomu czystości i estetyki, } \\
\text { - reurbanizacja oraz rekultywacja terenów zdegradowanych, } \\
\text { - powstrzymanie postępującej dekapitalizacji najcenniejszych } \\
\text { obiektów w strukturze miejskiej, } \\
\text { - zagospodarowanie dysfunkcyjnych części śródmiejskich, } \\
\text { - częściowa gentryfikacja części śródmiejskich. }\end{array}$ \\
\hline
\end{tabular}

Źródło: [Mierzejewska, 2010, s. 77] 


\section{STRATEGIE RELACYJNE SAMORZĄDÓW}

Funkcjonowanie jednostek samorządu terytorialnego bardzo często opiera się na tworzeniu relacji o charakterze współpracy. Gminy mogą tworzyć różnego rodzaju stowarzyszenia, związki i porozumienia, które służą realizacji celów, które stosunkowo trudno osiągnąć, działając w pojedynkę [Dz.U. 1990 nr 16, poz. 95, art. 8, art. 10, art. 81]. Należy jednak wskazać na możliwość zachodzenia innych typów relacji, w tym przede wszystkim na możliwość konkurowania między gminami (konkurencja w ujęciu strategii czystej), ale również na strategię koopetycji, która stanowi ewolucyjne rozwinięcie dotychczasowych osiągnięć w tym zakresie. Ewa Stańczyk-Hugiet [2013, s. 7] uznaje relacje międzyorganizacyjne wręcz za centralny problem badawczy we współczesnych naukach o zarządzaniu, w tym w szczególności w jej subdyscyplinie, jaką stanowi zarządzanie strategiczne. Zaznacza przy tym, że głównym przedmiotem badań są relacje współdziałania. Podstawowe typy relacji międzyorganizacyjnych ukazano na rysunku 1.

Nurt relacji międzyorganizacyjnych należy obecnie do silnie eksplorowanych w warunkach polskich. Mariusz Bratnicki [2009], Wojciech Czakon [2012], Ewa Stańczyk-Hugiet [2013] czy Agnieszka Zakrzewska-Bielawska [2014] to czołowi badacze naukowi w tym zakresie. Wskazuje się na silne umocowanie relacji między organizacjami na gruncie podejścia zasobowego. A za główną przesłankę tworzenia relacji o charakterze współpracy uznaje się ograniczony dostęp do różnego rodzaju zasobów - materialnych i niematerialnych, co skutkuje koniecznością ich współdzielenia, również w przypadku podmiotów, które są wobec siebie bezpośrednimi lub pośrednimi konkurentami. W takim kontekście coraz częściej dyskutowanym podejściem kształtowania relacji międzyorganizacyjnych jest koopetycja, której poświęcono kolejny rozdział artykułu. Koopetycja jawi się tu jako kolejny etap rozwoju typów relacji międzyorganizacyjnych. 


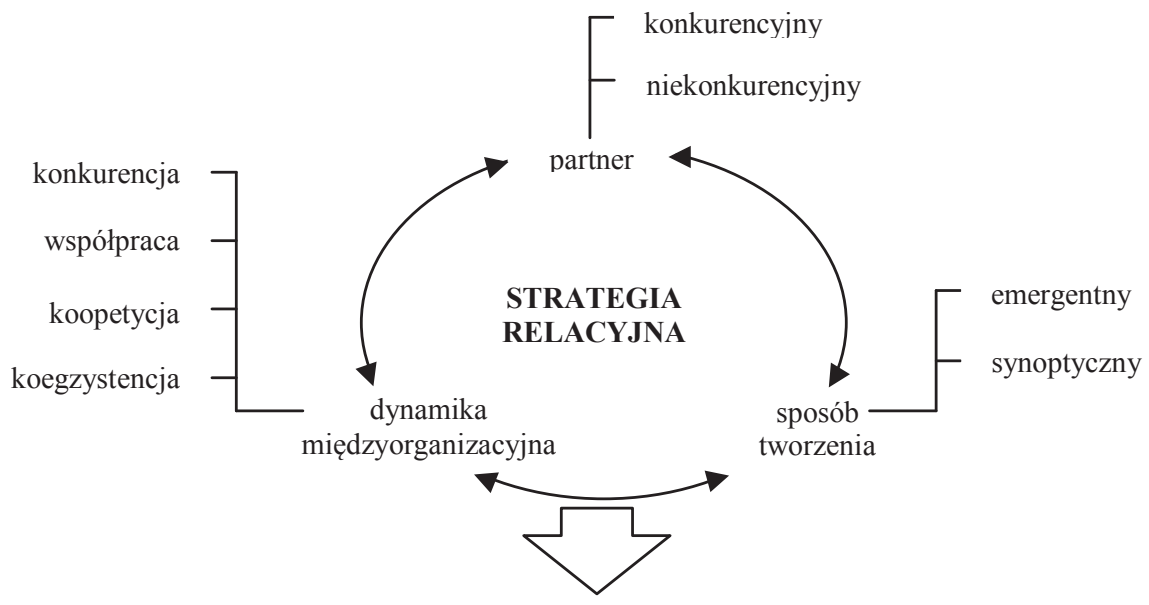

wybory strategiczne na poziomie korporacji

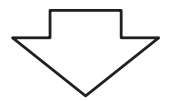

wybory strategiczne na poziomie jednostek biznesu

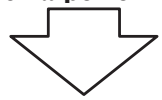

wybory strategiczne na poziomie funkcjonalnym

Rysunek 1: Typy strategii relacyjnych - międzyorganizacyjnych

Źródło: [Zakrzewska-Bielawska, 2014, s. 24]

\section{RELACJE KOOPETYCJI WEWNĄTRZ OBSZARÓW METROPOLITALNYCH}

Koopetycja stanowi jedną z silnie rozwijanych współcześnie koncepcji zarządzania organizacjami tak na gruncie teorii naukowej, jak i praktyki gospodarczej. Może być również z powodzeniem wykorzystywana na polu funkcjonowania jednostek samorządu terytorialnego. Brak jednak obecnie wyczerpujących opracowań naukowych charakteryzujących koopetycję w odniesieniu do działalności jednostek samorządowych. Podejmowana problematyka stanowi zatem lukę badawczą, której wypełnienie może przyczynić się do rozwiązania problemów natury teoretycznej (naukowej) oraz praktycznej (aplikacyjnej). 
Koopetycja w pierwotnym znaczeniu oznaczała jednoczesne występowanie współpracy i konkurencji pomiędzy tymi samymi przedsiębiorstwami [Brandenburger, Nalebuff, 1998, s. 11-39]. Autorzy badali jednak koopetycję na gruncie teorii gier, stąd takie wyjaśnienie specyfiki koopetycji w odniesieniu do funkcjonowania organizacji czy też innych podmiotów (samorządów) wydaje się nie w pełni adekwatne i satysfakcjonujące. Joanna Cygler [2007, s. 64] postuluje przyjęcie rozwiniętej definicji pojęcia koopetycja, w ramach której koopetycja stanowi „układ strumieni jednoczesnych i współzależnych relacji konkurencji i kooperacji między konkurentami, zachowującymi swoją odrębność organizacyjną. Relacje kooperacyjne tworzone są do realizacji konkretnych celów strategicznych w określonym horyzoncie czasowym, a ich konsekwencje mają istotny wpływ na strategię rozwoju zaangażowanych stron". Definicja autorstwa Joanny Cygler osadza koopetycję na gruncie dyscypliny zarządzania strategicznego - ta służy bowiem realizacji celów o charakterze strategicznym. W swojej definicji autorka odnosi się również do kwestii związanych z relacjami międzyorganizacyjnymi. Wypadkową tych dwóch może być uznanie koopetycji za jedną ze strategii relacyjnych. Takie wyjaśnienie znajduje swoje uzasadnienie na polu rosnącej roli wyłaniających się i rozwijanych sieci międzyorganizacyjnych oraz całego paradygmatu sieciowego [Czakon, 2013, s. 7-8; Zakrzewska-Bielawska, 2014, s. 20].

Koopetycja, której inspiracji można doszukiwać się w wielu źródłach, w tym między innymi we wspominanej już wcześniej teorii gier, ale również w teorii kosztów transakcyjnych czy w ramach podejścia zasobowego, stanowi ciekawy fenomen łączenia ze sobą dwóch sprzecznych logik postępowania - konkurencji oraz kooperacji. Koopetycja bywa określana w literaturze przedmiotu mianem kooperacji między konkurentami. Kluczowe na tym etapie prowadzenia wywodu wydaje się pytanie o zakres przedmiotowy (rodzaj zasobów) konkurencji w przypadku funkcjonowania jednostek samorządu terytorialnego tworzących obszary metropolitalne. Podstawowy przedmiot (zasób) walki konkurencyjnej gmin stanowią potencjalne nowe przedsiębiorstwa (szerzej organizacje) oraz potencjalni nowi mieszkańcy, którzy to w znacznym stopniu determinują tempo rozwoju społeczno-gospodarczego samych gmin, jak i w szerszym ujęciu całego obszaru metropolitalnego. Warto w tym miejscu wskazać na możliwość zachodzenia zjawiska koopetycji między obszarami metropolitalnymi. Pojemność adaptacyjna gmin, rozumiana jako zdolność do przyjmowania nowych przedsiębiorstw i mieszkańców, ma charakter ograniczony - rywa- 
lizacja o ograniczone zasoby odbywa się również przy wykorzystaniu ograniczonych zasobów wewnętrznych gmin - ich potencjału wewnętrznego. Ograniczony zasób wewnętrzny stanowi w głównej mierze będąca w dyspozycji samorządu przestrzeń, która w wyniku dynamicznych procesów urbanizacyjnych, w tym wielu nacechowanych pejoratywnie, ulega bardzo szybkiemu wyczerpywaniu się, a ocena stanu jej zagospodarowania bardzo często budzi wątpliwości z perspektyw jej funkcjonalności, użyteczności, estetyki, intensywności lub ekstensywności.

\section{DYLEMATY POZNAWCZE DOTYCZACE KOOPETYCJI WEWNĄTRZ OBSZARÓW METROPOLITALNYCH}

Z perspektywy problematyki podejmowanej w opracowaniu - powiązania kooepetycji z funkcjonowaniem obszarów metropolitalnych - rodzi się kilka istotnych dylematów poznawczych, które mogą stanowić w przyszłości źródło eksploracji naukowej i główny kierunek podejmowanych wysiłków badawczych.

Kluczowe wydaje się przede wszystkim zidentyfikowanie zakresów przedmiotowych koopetycji wewnątrz obszarów metropolitalnych $-\mathrm{tj}$. między gminami je tworzącymi. Zakresy należy w tym przypadku utożsamiać z obszarami funkcjonalnymi działalności gmin, w ramach których mogą one ze sobą konkurować oraz kooperować, tworząc w ten sposób strumień przepływu jednoczesnych relacji. W kwestii tej proponuje się przyjąć podstawowy podział na działania (zadania) w zakresie takich aspektów, jak: gospodarka, społeczeństwo, środowisko, przestrzeń i infrastruktura. Wielość dostępnych typologii w tym zakresie rodzi różnorodne możliwości analizy.

Element stanowiący naturalny następnik procesu identyfikacji zakresów może stanowić ocena stopnia - nasilenia strumieni relacji. Zasadniczy problem w tym zakresie stanowić może kwestia zobiektywizowania potencjalnego narzędzia służącego pomiarowi badanej cechy.

Kolejny dylemat poznawczy stanowić może zasięg geograficzny zachodzenia relacji i charakter koopetycji oraz charakter układu powiązań - hierarchiczny, biegunowy, sieciowy, inny. Z perspektywy specyfiki polskich obszarów metropolitalnych, w których dominuje (poza śląskim obszarem metropolitalnym i trójmiejskim obszarem metropolitalnym) układ monocentryczny (jedno miasto centralne oraz kilkanaście lub kilkadziesiąt są- 
siadujących jednostek osadniczych niższego rzędu), określenie tych zmiennych wydaje się niezwykle ważkim problemem.

Zakłada się przeprowadzenie badań w odniesieniu do gmin tworzących poszczególne obszary metropolitalne, tymczasem zasadne jest wskazanie na inne poziomy zachodzenia relacji koopetycyjnych, w tym na koopetycję pomiędzy obszarami metropolitalnymi (zasięg krajowy i międzynarodowy) czy koopetycję wewnątrz poszczególnych gmin - instytucje, organizacje, podmioty gospodarcze.

Wreszcie weryfikacji wymaga stopień formalizacji układów koopetycyjnych. W głównej mierze formalizacji podlegają obszary współpracy między gminami tworzącymi stowarzyszenia, związki czy inne struktury koopetycji. Czy oznacza to jednak, że wszystkie pozostałe obszary działalności nacechowane są nastawieniem konkurencyjnym? To kolejny dylemat poznawczy wymagający rozstrzygnięcia.

Spośród szerokiej listy problemów badawczych, które cechują wysokie walory poznawcze, należy również wskazać na oczekiwane - z perspektywy władz samorządowych, społeczności lokalnej, innych grup interesariuszy gminnych - i rzeczywiste korzyści stosowania koopetycji.

podsumowanie

Paralelność i analogia stosowania koncepcji i metod oraz zachodzenia zjawisk, którymi zajmuje się zarządzanie strategiczne, pomiędzy sektorem rynkowym i nierynkowym (publicznym), w tym kwestie związane z kształtowaniem relacji międzyorganizacyjnych, rodzą słuszne podstawy do uznania koopetycji wewnątrz obszarów metropolitalnych za interesujący problem badawczy. A stan wiedzy na jej temat świadczy o istotnej luce poznawczej w tym zakresie.

W artykule wskazano na główne przesłanki podjęcia badań w przedmiotowej problematyce, wskazując na szczególną rolę, jaką odgrywają obszary metropolitalne w krajowym systemie społeczno-gospodarczym. Nakreślono również kluczowe dylematy poznawcze związane z koopetycją wewnątrz obszarów metropolitalnych, które mogą zostać podjęte w przyszłych badaniach.

\section{LITERATURA}

Brandenburger A., Nalebuff B., (1998), Co-opetition. A revolutionary mindset that combines competition and cooperation, Currency Paperback, New York. 
Bratnicki M., (2009), Ujęcie konfiguracyjne przedsiębiorczych zdolności organizacji, „Zeszyty Naukowe Uniwersytetu Ekonomicznego w Poznaniu”, nr 129, Poznan.

Cygler J., (2007), Kooperencja - nowy typ relacji między konkurentami, „Organizacja i Kierowanie", nr 2 (128).

Czakon W., (2012), Sieci w zarzadzaniu strategicznym, Wolters Kluwer, Warszawa.

Grochowski M., (2010), Samorzad na obszarach metropolitalnych. Raport z badań, „Samorząd Terytorialny”, 6/2010.

Izdebski H., (2006), Zadania metropolitalne i instytucjonalne sposoby ich realiza$c j i$, ,Samorząd Terytorialny”, 6/2006.

Jędralska K., Czech A., (2011), O naturze niepewności i jej interpretacjach, „Master of Business Administration", 3/2011.

Lackowska M., (2009), Dlaczego Polsce potrzebna jest ustawa metropolitarna? Ograniczenia dobrowolnej wspótpracy samorzadów w obszarach metropolitarnych, „Samorząd Terytorialny”, 3/2009.

Markowski T., Marszał T., (2006), Metropolie. Obszary metropolitalne. Metropolizacja. Problemy i pojęcia podstawowowe, Komitet Przestrzennego Zagospodarowania Kraju PAN, Warszawa.

Mantey D., (2013), Potrzeba zintegrowanego zarzadzania miastami i obszarami metropolitalnymi, „Samorząd Terytorialny”, 6/2013.

Mierzejewska L., (2010), Rozwój zrównoważony miasta. Zagadnienia poznawcze i praktyczne, Wydawnictwo Naukowe UAM, Poznań.

Parysek J.J., Mierzejewska L., (2009), Problemy funkcjonowania i rozwoju miast polskich z perspektywy 2009 roku [w:] J. J. Parysek (red.), Wybrane problemy miast i aglomeracji miejskich na poczatku XXI wieku, „Biuletyn Instytutu Geografii Społeczno-Ekonomicznej i Gospodarki Przestrzennej UAM”, nr 6.

Parysek J.J., (2013), Polityka miejska i wspótczesne problemy funkcjonowania i rozwoju miast polskich, [w:] W. M. Gaczek (red.), Dynamika, cele i polityka zintegrowanego rozwoju regionów. Apekty teoretyczne i zarzadzanie w przestrzeni, Bogucki Wydawnictwo Naukowe, Poznań.

Stańczyk-Hugiet E., (2013), Dynamika strategiczna w ujęciu ewolucyjnym, Wydawnictwo Uniwersytetu Ekonomicznego we Wrocławiu, Wrocław.

Ustawa z dnia 8 marca 1990 r. o samorzadzie gminnym, Dz.U. $1990 \mathrm{nr}$ 16, poz. 95.

Zakrzewska-Bielawska A., (2014), Ewolucja szkót strategii: przegląd głównych podejść $i$ koncepcji, [w:] R. Krupski (red.), Zarzadzanie strategiczne. Rozwój koncepcji i metod, „Prace Naukowe Wałbrzyskiej Wyższej Szkoły Za- 
rządzania i Przedsiębiorczości”, t. 27, Wydaw. Wałbrzyskiej Wyższej Szkoły Zarządzania i Przedsiębiorczości, Wałbrzych.

https://mac.gov.pl/aktualnosci/25-lat-samorzadnosci-w-polsce-obchody [28.04.2015].

\title{
COOPETITION OF COMMUNITIES IN POLISH METROPOLITAN AREAS
}

\begin{abstract}
A b s t r a c t: Article discusses the relationship of a coopetition within metropolitan areas in Poland. Author characterizes the main features of metropolitan areas (object of research) and coopetition (subject of research). It was pointed out the place and the role of metropolitan areas, its development problems, the concept of coopetition, its main cognitive dillemas. The paper is a contribution to further research on coopetition within metropolitan areas.
\end{abstract}

K e y w o r d s: coopetition; competitiveness; cooperation; metropolitan areas. 